\title{
Study on Techno Economic Status of the Local and Migratory Fishermen in Cochin Back Waters
}

\author{
P. Srikanth ${ }^{1 *}$, A. Balasubramanian ${ }^{2}$, V. Reddy Naik ${ }^{3}$, G. Suresh ${ }^{4}$ and B. Manoj Kumar ${ }^{1}$ \\ ${ }^{1}$ Department of Fisheries Engineering and Technology, KUFOS Panangad, \\ Kochi, Kerala, India \\ ${ }^{2}$ Fisheries Research Station, Undi, AP, India \\ ${ }^{3}$ College of Fisheries, Mangalore, Karnataka, India \\ ${ }^{4}$ College of Fisheries, Muthukur, Andhra Pradesh, India \\ *Corresponding author
}

\section{A B S T R A C T}

\begin{tabular}{l} 
Ke y w o r d s \\
$\begin{array}{l}\text { Migratory fishermen, } \\
\text { Local fishermen, Gillnet, } \\
\text { Catch per Unit Effort, } \\
\text { Cost analysis }\end{array}$ \\
Article Info \\
$\begin{array}{l}\text { Accepted: } \\
\text { 02 May } 2018 \\
\text { Available Online: } \\
\text { 10 June } 2018\end{array}$ \\
\hline
\end{tabular}

Keywords

Migratory fishermen, Catch per Unit Effort, Cost analysis

\section{Article Info}

Accepted: Available Online:

10 June 2018
This study on techno- economic study of the local and migratory fishermen in the Cochin backwaters was conducted from June 2016 to May 2017. The estimates of the mean monthly CPUE for local and migratory fisherman were $11.55 \mathrm{~kg}$ and $24.61 \mathrm{~kg}$ respectively. The catch and resultant income were more than double in the case of migratory fishermen compared to the local fishermen. The net profit ratio and the ROI showed that profitability is very high in the case of migratory fishermen. The amount of investment in fixed aspects was very less in this case, compared to the local fishermen. The payback period was 5.4 months in the case of local fishermen whereas it was only 1.8 months in migratory fishermen. It leads to high consumption of fuel energy in the case of the local fishermen which ultimately affect the livelihood of the local fishermen. It indicates that further better development in design, netting materials, operation aspects and conservation measures are to be implemented for maintaining the stock fishery resources in Cochin back waters.

\section{Introduction}

Fishing is predominant activity in the backwaters of Cochin mainly by traditional fishermen using plank built canoes and drift gillnets. As the back water serves as one of the potential fishing ground, it lures fishermen from different part of Kerala and neighbour states. Of them, a group fishermen migrated from Unsoor (near Mysore), Karnataka to Kerala aiming the bulk of fish catch from this backwaters. The migratory fishermen are mainly inhabited at Nettoor, Vypin and
Mulavukadu region of the Cochin backwaters. They belong to eight families and chose their main profession as fishing in backwaters of Cochin. Two families are inhabited in Nettor while three at Mulavukad and Vypin region. In each family, there are about 4-5 members used to involve in fishing activities. The reason for the migration is in search of work and better price for their catch in Kerala. They could earn 10 times more in Kerala compared to they get from Karnataka. Better technologies obviously have a better access to fishery resources despite high cost. A 
technology can be considered as an appropriate and successful only if it lowers the cost of production per unit of catch and raises the productivity. Consequently, it becomes imperative to study and monitor the economic performance of different fishing enterprises. The pattern of capital investment, crew size, sharing system, soaking time of fishing gears and actual fishing duration differ from one fishing system to another.

The technical and economical efficiency of a system are considered equally important. Both the superior technical performance from a fishing technologist's point of view, and the economic behaviour or economic health of the system from an economist's point of view, especially in the long run, are very important for every system being maintained sustainably. Thus, a technically superior fishing method with high earning capacity is an ideal one. Njoku (1991) studied comparative efficiency and techno-economics of multifilament and monofilament gillnets operated in the Oguta lake, Nigeria and reported the comparative catch efficiency, species composition and total biomass, cost and financial returns of the nets. Owing to these, this study was aimed to appraise the major salient features and techno economic status of the local and migratory fishermen inhabited in the Cochin back waters.

\section{Materials and Methods}

The present study was carried out for a period of one year from June 2016 to May 2017 in Cochin backwaters of Kerala. A preliminary survey was conducted along the Cochin back waters to identify the important settlements of migratory and local fishermen. Based on the survey, the landing centres identified for the study were Kumbalam, Nettor, Vypin and Mulavukadu of Cochin. Various data on techno economic features of the fishing gears and crafts being operated by migratory and local fishermen, gear-wise total catch and catch composition were collected fortnightly through questionnaire and personal observations.

\section{Design and technical details of crafts}

Various technical details about the crafts such as material, Length Over All (LOA), beam, draft, type of construction, preservatives used, type of engine, mode of operation and fishing season were collected. The physical dimensions of the craft, horsepower of the engine, were also documented

\section{Catch composition and catch per unit effort estimation}

Fish catch data were collected from one boat from each local and migratory fisherman visiting every landing centre fortnightly. The catch collected from all the centres were pooled together to estimate total catch landing of the each group. The number of fishing days was ascertained based on the personal interview with the fishermen. Based on that, the total number of boat days was calculated multiplying it with the boats being operated during the month. In addition, the different mesh sizes of gear used by the fishermen on the particular day were also measured. Catch per unit effort (CPUE) and number of boat days of both groups of fishermen were estimated. 'Student's t-test was used for testing the significance between CPUE from both the group of fishermen, gear wise catch composition and different type of gillnets. This statistical analysis was carried out using SPSS software.

\section{Techno-economic aspects}

Two pre-tested interview schedules viz., schedule I and II were used for collecting the investment and operational details of the selected fishing units (Panayotou et al., 1985). 
Schedule I was used to gather information relating to the dimensions of the gear, capital investment and other fixed overheads of the unit. This information was collected only once at the initial stage of the study. Schedule II was used on weekly basis to collect the operational cost and revenue from each of the unit during the period from June 2016 to May 2017.

Interactions with the operators of the units and with commission agents/middlemen were carried out to verify and ascertain the validity of the data. The economic performance of the systems was assessed using analytical tools such as, Return on Investment (ROI), Internal Rate of Return (IRR), sensitivity analysis, pay-back period and factor productivity.

\section{Results and Discussion}

\section{Analysis of Catch per Unit Effort (CPUE)}

Comparison of catch and effort analysis in terms of boat days for local and migratory fisherman during the period June 2016 to May 2017 is presented in the table 1. Local and migratory fisherman recorded maximum CPUE in the month of June and minimum during the month of May. CPUE obtained by the Migratory fishermen was comparatively higher than Local fishermen.

The catch per unit effort was $2402 \mathrm{~kg}$ for local fishermen and $2569 \mathrm{~kg}$ for migratory fishermen for the month of June 2016. The mean monthly CPUE for local and migratory fisherman are $11.55 \mathrm{~kg}$ and $24.61 \mathrm{~kg}$ respectively. It is evident that CPUE is nearly two to three times in the case of migratory fishermen compared to local fishermen.

It is also known that CPUE is high during the monsoon season when compared to the off season. It implies that the mean CPUE for migratory fishermen is significantly $(\mathrm{P}<0.023)$ higher than that of local fishermen.
If the economic life of both sectors is appraised for the next 5 years, the amount of revenue and operating expenses would remain same during the period being assessed. Thus, it is assumed that the annual cash inflow also over the period of next five years would be uniform. The respective estimated annual cash inflow would be Rs. 2,13,960 and Rs.3,33,560 for local fishermen and migratory fishermen (Table 2).

It is understood from the profitability statement that annual turnover (revenue) higher in the case of migratory fishermen when compared to the local fishermen. The net profit ratio is $52.64 \%$ in case of migratory fishermen where as it is only $48.52 \%$ in the other case. The return on investment (ROI) is found to be very high in case of migratory fishermen and it is calculated as $662.5 \%$ of the total investment. However, the ROI is $207.32 \%$ in the case of local fishermen. The net profit ratio and the ROI clearly show that profitability is very high in case of migratory fishermen despite less amount of investment in fixed aspects when compared to the local fishermen.

The total investment to be made by local fisherman is Rs. 67,400 where as it is only Rs. 26,700 in case of case of migratory fishermen (Table 3). The amount of working capital required for the traditional fishermen is Rs.17, 397 per annum while it is Rs.19,705/- for migratory fishermen.

The payback period is 5.4 months in case of the local fishermen where as it is only 1.8 months in case of migratory fishermen. Internal rate of returns (IRR) is worked out to the $210.03 \%$ in case of local fishermen while it is $680.50 \%$ in case of migratory fishermen. The payback period and IRR indicate that migratory fishermen are safer in the recovery of original investment and also in earning the maximum profit. 
Table.1 Monthly average catch and effort of the local and migratory fisherman during the period from June 2016 - May 2017

\begin{tabular}{|c|c|c|c|c|c|c|c|c|c|c|}
\hline & \multicolumn{5}{|c|}{ Local fisherman } & \multicolumn{5}{|c|}{ Migratory fisherman } \\
\hline Month & $\begin{array}{c}\text { No. of } \\
\text { boats } \\
\text { observed } \\
\text { for } \\
\text { collecting } \\
\text { catch } \\
\text { details }\end{array}$ & $\begin{array}{l}\text { No. of } \\
\text { fishing } \\
\text { days }\end{array}$ & $\begin{array}{l}\text { Boat } \\
\text { days }\end{array}$ & $\begin{array}{c}\text { Total } \\
\text { weight } \\
\text { of fish } \\
\text { landed } \\
\text { in a } \\
\text { month } \\
\text { Kg) }\end{array}$ & $\begin{array}{c}\text { CPUE } \\
\text { (Kg/trip) }\end{array}$ & $\begin{array}{l}\text { Avg. no } \\
\text { of boats } \\
\text { operated } \\
\text { / landed } \\
\text { per day }\end{array}$ & $\begin{array}{c}\text { N0.of } \\
\text { boats } \\
\text { observed } \\
\text { for } \\
\text { collecting } \\
\text { catch } \\
\text { details }\end{array}$ & $\begin{array}{l}\text { Boat } \\
\text { days }\end{array}$ & $\begin{array}{c}\text { Total } \\
\text { weight of } \\
\text { fish } \\
\text { landed in } \\
\text { a month } \\
\mathrm{Kg})\end{array}$ & $\begin{array}{c}\text { CPUE } \\
\text { (Kg/trip) }\end{array}$ \\
\hline June & 6 & 20 & 120 & 2402 & 20.01 & 2 & 20 & 40 & 2569 & 64.225 \\
\hline July & 6 & 22 & 132 & 2422 & 18.34 & 2 & 26 & 52 & 2458 & 47.269 \\
\hline Aug & 5 & 22 & 110 & 1787 & 16.24 & 2 & 30 & 60 & 1897 & 31.617 \\
\hline Sept & 5 & 22 & 110 & 1898 & 17.25 & 2 & 26 & 52 & 1804 & 34.692 \\
\hline Oct & 5 & 20 & 100 & 1233 & 12.33 & 2 & 30 & 60 & 1177 & 19.616 \\
\hline Nov & 5 & 20 & 100 & 1152 & 11.52 & 2 & 24 & 48 & 908 & 18.917 \\
\hline Dec & 5 & 20 & 100 & 1028 & 10.28 & 2 & 26 & 52 & 837 & 16.096 \\
\hline Jan & 6 & 20 & 120 & 971 & 8.09 & 2 & 27 & 54 & 706 & 13.074 \\
\hline Feb & 5 & 18 & 90 & 556 & 6.17 & 2 & 25 & 50 & 555 & 11.1 \\
\hline Mar & 5 & 20 & 100 & 635 & 6.35 & 2 & 26 & 52 & 903 & 17.365 \\
\hline Apr & 4 & 18 & 72 & 445 & 6.18 & 2 & 25 & 50 & 557 & 11.14 \\
\hline May & 4 & 21 & 84 & 488 & 5.80 & 2 & 27 & 54 & 554 & 10.25 \\
\hline
\end{tabular}

Table.2 Annual economical profitability among local and migratory fishermen

\begin{tabular}{|l|c|c|}
\hline \multicolumn{1}{|c|}{ Item } & Local fisherman & Migratory fisherman \\
\hline Investment & 67,400 & 26,700 \\
\hline Revenue & $2,88,000$ & $3,36,000$ \\
\hline Total variable cost & $1,27,764$ & $1,43,160$ \\
\hline Total fixed cost & 20,500 & 15,950 \\
\hline Total cost & 148264 & 159110 \\
\hline Net profit & $1,39,736$ & $1,76,890$ \\
\hline Net profit ratio & $48.52 \%$ & $52.64 \%$ \\
\hline Rate of returns (\%) & $207.32 \%$ & $662.50 \%$ \\
\hline IRR (\%) & $216.03 \%$ & $680.50 \%$ \\
\hline
\end{tabular}


Table.3 Total cost of the project

\begin{tabular}{|c|c|c|}
\hline Costs & $\begin{array}{c}\text { Local } \\
\text { Fishermen }\end{array}$ & $\begin{array}{l}\text { Migratory } \\
\text { Fishermen }\end{array}$ \\
\hline \multicolumn{3}{|l|}{ Fixed $\operatorname{assets}(\mathbf{A}):$} \\
\hline Craft & 20,000 & 7000 \\
\hline Engine & 30000 & Nil \\
\hline Total & 50000 & 7000 \\
\hline \multicolumn{3}{|l|}{ Working capital(B): } \\
\hline Cost of the gear & 7167 & 11250 \\
\hline Ice & 480 & 480 \\
\hline Repair and maintenance & 3000 & 1000 \\
\hline Sinkers and floats & 3750 & 6775 \\
\hline Cost of petrol & 2800 & o \\
\hline Food and water & 200 & 200 \\
\hline Total & 17397 & 19705 \\
\hline Total cost of the project $(A+B)$ & 67397 & 26705 \\
\hline Rounded Off to & 67400 & 26700 \\
\hline Payback period & 5.4 months & 1.8 months \\
\hline Depreciation & 10,000 & 1,400 \\
\hline IRR & $216.03 \%$ & $680.50 \%$ \\
\hline
\end{tabular}

\section{Catch per unit effort}

The CPUE is studied to find out the intensity of fishing. It can be calculated monthly and annually and used as index of relative abundance landings from all gears and fishing methods. Catch per unit effort (CPUE) is defined as the catch obtained in one tow of the net operated once per site, and is expressed as $\mathrm{kg} \cdot \mathrm{hr}^{-1}$. The peak fishing season for the local and migratory fishermen was June to-October. The CPUE obtained from migratory fishermen washigher than local fishermen during the study period.

It might be due to the favorable conditions existed in the back water of the Cochin during the southwest monsoon with the influence of fresh water inflow into the backwaters from the rivers. Gillnets with varying mesh sizes were employed along the southern zone contributing $76.3 \%$ of the total catch of Vembanad back waters. More than 50\% of fish production in the northern zone of backwater was contributed by fixed gears such as stake nets and Chinese dip nets. Gill net, seines, hook and line, cast net and crab ring also contributed to the annual fishery. It was observed that gill nets of various mesh sizes were used by both the migratory and local fishermen.

During the study it was found that the mean monthly CPUE obtained between local and migratory fisherman were significantly different. According to Asha et al., (2014) in Vembanad lake gill net showed highest CPUE of $3.04 \mathrm{~kg} \cdot \mathrm{h}^{-1}$ followed by stake net having $2.43 \mathrm{~kg} \cdot \mathrm{h}^{-1}$, Chinese dip net $2.01 \mathrm{~kg} \cdot \mathrm{h}^{-1}$, seine net with $1.2 \mathrm{~kg} \cdot \mathrm{h}^{-1}$, cast net with $0.72 \mathrm{~kg} \cdot \mathrm{h}^{-1}$, hook and line with $0.34 \mathrm{~kg} \cdot \mathrm{h}^{-1}$ and traps with $0.26 \mathrm{~kg} \cdot \mathrm{h}^{-1}$. The difference in the catch observed in the present study may be due to restricted study to few landing centers of the Vembanad Lake despite the former study covered a wider area. The high CPUE 
obtained for the migratory fishermen is an indication of their better income from fishing.

\section{Techno-economic analysis of fishing gears and crafts}

Three types of the gillnets operated by the migratory fishermen are all bottom set gill nets while the local fishermen operate both bottom gillnet such as 'njanduvala' and surface gillnet 'ozhukuvala' and 'thiruthavala'. These gillnets operated with the aim to target a particular group of fish such as 'karimeenvala' (Etroplus), 'koori vala' (cat fish) and Njanduvala (crab net).

Pauly (1991) studied the commercially important fishing gears in Vembanad Lake and described in detail the design aspects, construction and operation 'of the important nets viz., stake nets, gill nets and Chinese nets. Gill nets operated in the Vembanad Lake have been reported by Shetty (1965). Kurup and Samuel (1985) classified gillnets into drift and set nets. Looppuvala', 'Ozhukkuvala, 'Hurasuvala' and 'karimeenvala' which come under driftnet while sand and koorivalacome under set net. The observations in the present study are also similar with above studies. The variation in the colloquial names of the gears occurs between the regions and it changes over the period also. The 'Karimeenvala' used by the local fishermen is a drift net but that of migratory fishermen is a bottom set net.

Gillnet fishing is a low energy fishing technique which is favored in the recent yeas in the contest of alarming the fuel cost. Saly (2003) studied technological and operational aspects gillnets of the Kerala and reported various mechanized, motorized and nonmotorized boats employed for the gillnet fishing by various traditional fishermen. In this study, it is found that only Coracle, locally known as "Kottavanchi" or "Vattavanchi" is used by the migratory fishermen of Cochin backwaters (Remesan and Ramachandran, 2005).

It was observed in the present study that each family of the migratory fishermen having 3-4 coracles of different sizes and they informed that the life span of a coracle is about 1 year. These coracles are brought from Karnataka. All members of the migrant fishermen family including women and children are experts in the operation of coracles. However, local fishermen operate only plank built canoes (Remesan, 2006) with or without fibre coating. The average life span of the craft is 10-15 years, the approximate cost of the craft and engine is Rs 20,000 and 30,000/-. Coracles are fabricated with wooden planks with coir ropes and a layer of pitch/tar is applied along the joining to make it water tight. A variety of woods are used for this type of construction. Commonly used wood are Mango wood, Sal wood, Anjili, Venteak and Maiuthe. Diameter of the coracleranges from $3-7 \mathrm{~m}$. Traditional preservatives like fish oil, cashew nut shell oil, tar, etc are used for the preservation. Total cost of a medium sized canoe ranges from Rs. 17, 000 to 20,000/- respectively. The observation in the present study was similar to the earlier studies conducted by various researchers though variation could be found in the fabrication cost of the crafts. It may be due to difference in the periods of study. The coracles are operated using oars while the crafts used by local fishermen are operated either by oars or long tailed outboard motor of Kirloslar make.

It is concluded that the profitability and annual turnover are higher in the case of migratory fishermen than the local fishermen. Similarly, the net profit ratio and the ROI are also high to the migratory fishermen. While comparing the economical status among the local and migratory fishermen, the later get benefited economically through less capital investment. 


\section{References}

Asha, C.V., Suson, P.S., Retina, C.I, and Nandan, S.B. 2014. Decline in Diversity and Production of Exploited Fishery Resources in Vembanad Wetland System: Strategies for Better Management and Conservation. Open Journal of Marine Science. 4, 344-357.

Balan, K., Panikkar, K. K. P., Jacob, T., Andrews, J., and Rajendran, V. 1989. Motorization of country craft in Keralaan impact study. CMFRI special publication. 45, 1-33.

Kurup, B. M., Sebastian, M. J., Sankaran, T. M., and Rabindranath, P. 1990. Exploited fishery resources of the Vembanad Lake. Part III. Clam fisheries. Mahasagar. 23(2); 127-137

Njoku, D. C. 1991. Comparative efficiency and techno-economics of multifilament and monofilament gillnets on the Oguta Lake, Nigeria. Fisheries research. 12(1); 23-30.

Panayotou, Y. Adulavidhaya K., Astachinda, $\mathrm{S}$, Isvilanand AS., and Jitsanganan T.
1985. Socio Economic Conditions of Coastal Fishermen in Thailand - A cross section profile. In: Small Scale Fisheries in Asia: Socio Economic Analysis and Policy. (Ed.) Panayotou, T. International Development Research Centre Ottawa.Pp 46-54.

Pauly, K.V. and Hridayanathan, C. 1991. Studies on the commercially important fishing gears of Vembanad Lake. Ph.D Thesis, Cochin University of Science and Technology.

Remesan, M. P. and Ramachandran. 2005. Gill nets for inland fishing in North Kerala. Fishery Technology. 42(2): 125134.

Shetty, H.P.C.1965. Observation on the fish and fisheries of Vembanad backwaters, Kerala. Proc. Natn. Acad. Sci. India., 35 (1): $115-130$.

Thomas, S. N., 2003. Gill nets of Kerala a study on technological and operational aspects. Ph.D. Thesis, Cochin University of Science and Technology.

\section{How to cite this article:}

Srikanth, P., A. Balasubramanian, V. Reddy Naik, G. Suresh and Manoj Kumar, B. 2018. Study on Techno Economic Status of the Local and Migratory Fishermen in Cochin Back Waters. Int.J.Curr.Microbiol.App.Sci. 7(06): 436-442.

doi: https://doi.org/10.20546/ijcmas.2018.706.049 